Ann. rheum. Dis. (1955), 14, 90.

\title{
A SIMPLE POSTURE METER
}

\author{
BY \\ R. HARRIS \\ From the Rehabilitation Unit, Devonshire Royal Hospital, Buxton
}

(RECEIVED FOR PUBLICATION SEPTEMBER 27, 1954)

In ankylosing spondylitis a simple method of measuring and recording spinal deformity is of value in assessing progress. Methods in use include serial photography, serial strip plaster-of-paris casts, and lead-moulding tracing the outline on to paper.

The apparatus described below is cheaper, less cumbersome, and more simple and convenient to use.

\section{Construction}

It consists of an upright, $6 \mathrm{ft} .3 \mathrm{in}$. high, mounted on a wooden base (Fig. 1). The upright is made of 3-in. $\times 2$-in. wood, and has fourteen horizontal holes bored through it, of 3/16-in. diameter, the centres being 3 in. apart. Through these closely fit cylindrical wooden rods, graduated in half inches. The rods vary in length, so that the longest projects 18 in. from the upright. Convenient projection lengths are five of $18 \mathrm{in}$., five of $10 \mathrm{in}$., and four of 6 in. Rubber caps at either end prevent displacement of the rods. Heel holds are fitted to the base.

\section{Method of Use}

The subject stands on the platform with his heels in the heel holds and back to the upright, and adopts his best posture. The rods are pushed through to press against the vertebral column and back of the head. The patient then steps off the platform, the distance by which each rod protrudes is noted, and the "spinal profile" is plotted on graph paper. Although this graph does not entirely exclude knee and hip deformity it provides a useful record of the patient's best standing position.

\section{Application}

The chart of an improving case of ankylosing spondylitis (Fig. 2) shows how easily progress can be assessed, without having to rely on clinical memory or elaborate records. The area between the profile and the upright gives an approximate estimate of the total deformity.

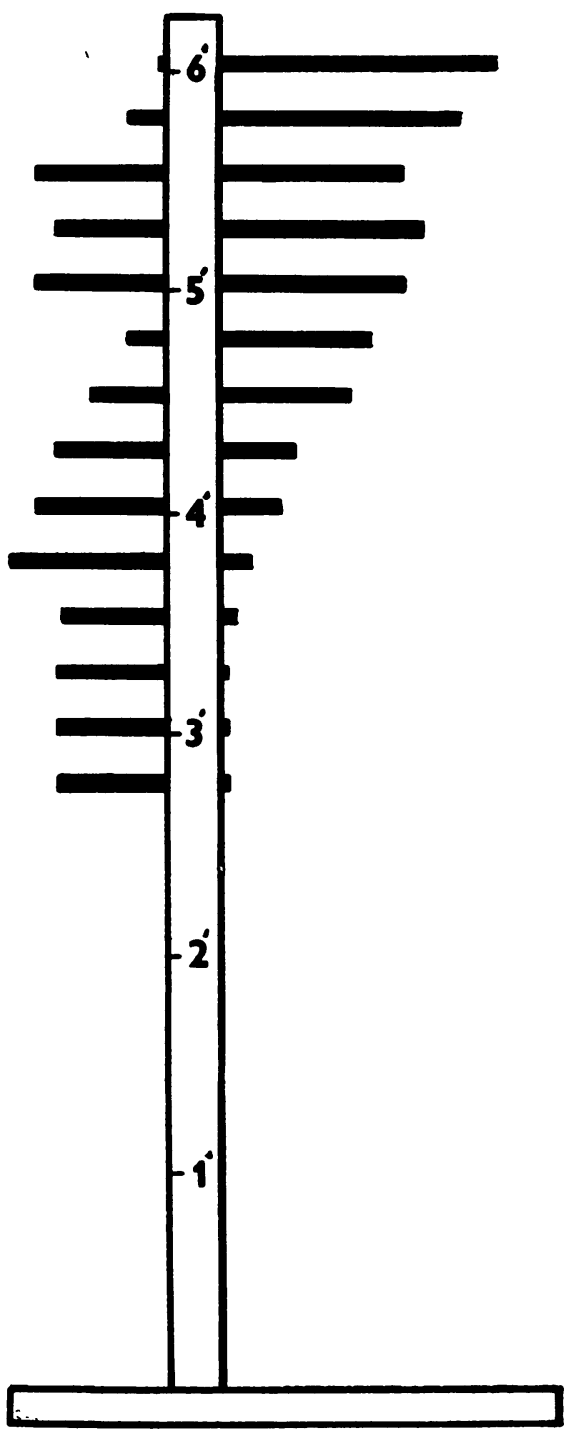

Fig. 1.-Posture meter, showing a spinal profile. 


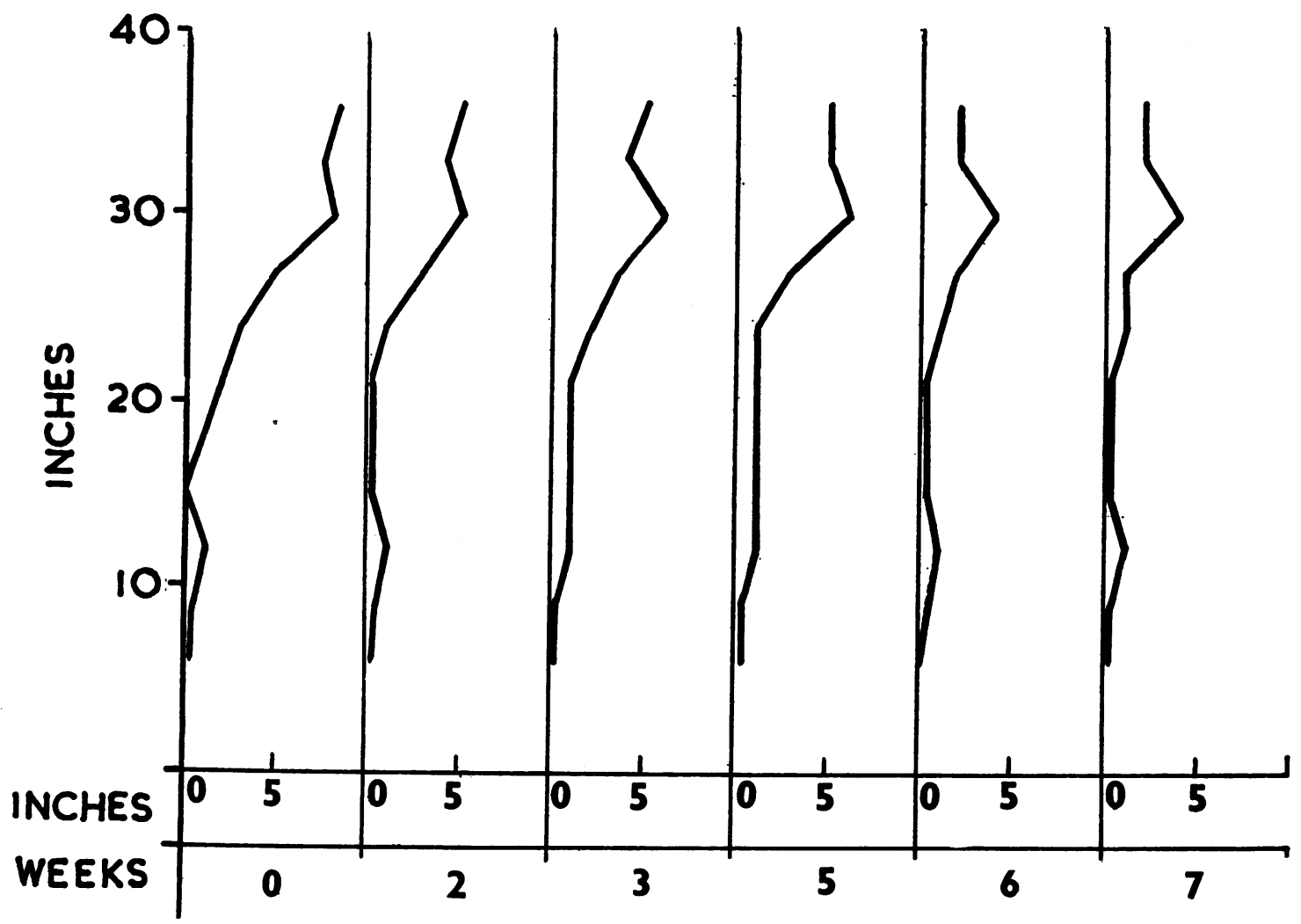

Fig. 2.-Serial recordings of an improving case of ankylosing spondylitis.

Un simple appareil à mesurer la posture RÉSUMÉ

On décrit un nouvel appareil qui permet de mesurer et enregistrer la difformité vertébrale dans la spondylite ankylosante. Il consiste d'un montant de plus de six pieds de hauteur sur une base pourvue de niches pour les talons. Ce montant est percé en ligne verticale de 14 trous équidistants traversés de barreaux mobiles et gradués. Le malade monte sur la base, le dos au montant, et adopte sa meilleure posture. On pousse alors les barreaux de manière qu'ils touchent l'épine et on note leur distance du montant. Cela permet une reconstruction graphique rapide et fidèle de la courbure vertébrale. On peut également déterminer la surface entre les lignes du montant et de la colonne et le chiffre obtenu peut servir d'indice de la difformité.
Un aparato simple para medir la postura Sumario

Se describo un aparato que permite medir y registrar la deformación vertebral en la espondylartritis anquilozante. Consiste de un montante de más de seis pies de altura, atravesado en línea recta de 14 varillas equidistantes, graduadas y móviles. El enfermo sube a la base del montante, pone los talones en los nichos provistos para ello y, con la espalda hacia el montante, adopta su mejor postura. Se empuja entonces las varillas para que toquen la espina y se nota la distancia del montante. Esto permite la reconstrucción gráfica rápida y fiel de la curvatura vertebral. Se puede también determinar la superficie comprendida entre la línea del montante y la de la espina y la cifra obtenida puede servir como indicio de la deformación. 